\title{
AT-RISK YOUTHS: NARRATING THEIR LIVED EXPERIENCES
}

\section{Pramela Krish $^{1 *}$ and Ramalinggam Rajamanickam²}

${ }^{1}$ Center for Research in Language and Linguistics, Faculty of Social Sciences and Humanities, Universiti Kebangsaan Malaysia, Selangor, MALAYSIA

${ }^{2}$ Faculty of Law, Universiti Kebangsaan Malaysia, Selangor, MALAYSIA

*Corresponding author: pramela@ukm.edu.my

Published online: 30 April 2021

To cite this article: Pramela Krish and Ramalinggam Rajamanickam. 2021. At-risk youths: Narrating their lived experiences. Kajian Malaysia 39(1): 99-115. https://doi.org/10.21315/km2021.39.1.5

To link to this article: https://doi.org/10.21315/km2021.39.1.5

\begin{abstract}
Youths are an important segment in a community as they are seen as the future leaders of a nation. One cannot deny that at-risk youths grow in environments not conducive to their well-being. These youths are victims of families where there is neglect, violence, poverty, sexual abuse and many other conflicts. Due to poverty and family instability, these youths are more sensitive to social ills. Based on a positive youth development perspective, this study aimed to share some real stories narratively from several identified at-risk youths via in-depth interviews conducted individually. The informants were selected by using purposive sampling taking into consideration their background and variables related to socio-economic status, dropout numbers from school and family instability. The study indicates that youths who are engaged in risk behaviours are capable of making some changes to take positive paths in life. This qualitative study will present several stories of youths who share their transformation journey and it is our belief that there are more youths in such predicament who need to receive interventions through education and values just like others and be empowered in society to become productive citizens of the nation.
\end{abstract}

Keywords: at-risk youths, socio-economic status, school dropouts, transformation, qualitative 


\section{INTRODUCTION}

Youth is best understood as a period of transition from the dependence of childhood to adulthood's independence and awareness of our interdependence as members of a community (UNESCO 2016). For statistical consistency across regions, United Nations (2001) defines youth as those persons between the ages of 15 and 24 years, without prejudice to other definitions by Member States. According to Dasar Pembangunan Belia Negara, youth is defined as any person between the age of 15 and 40 (and recently proposed to be lowered to 30), and the Akta Kanak-Kanak 2001 defines any person under the age of 18 as children. In the year 2018, statistics show that there are 15.1 million youths (or $46.64 \%$ of the population) in the Malaysia.

This period is characterised by physical change, the quest for independence exploring new behaviours, the strengthening of peer relations, sexual awakening and experimentation, pressure by family, school and peer. At this phase of life cycle, youths undergo many challenges and some even end up being at-risk. To be more specific, Adverse Childhood Experiences (ACEs) are stressful events occurring in childhood which include domestic violence, parental abandonment, a parent with a mental health condition, being the victim of abuse and neglect, a member of the household being in prison, and growing up in a household where adults experience alcohol and drug use (Public Health Scotland 2019).

It is also said that ACEs are potentially traumatic as the events that happen to a child to the age of 17 can have negative and lasting effects on health and wellbeing. It normally has a tremendous impact on future violence and victimisation. However, children's positive experience or protective factors can prevent them from experiencing adversity and can protect them against many of the negative outcomes even after adversity has occurred. This is in line with the Resilience theory (Zimmerman 2013) that refers to the process of overcoming the negative effects of risk exposure, coping successfully with traumatic experiences and avoiding negative trajectories associated with risks. A key requirement of resilience is the presence of both risk and the promote factors that either help adolescence face risk and bring out positive outcome or reduce the negative outcome.

It is possible to identify such at-risk youths much earlier on the basis of behaviours, circumstances, environment and developmental patterns. Although we do not have specific answers, youths can be at risk despite their ethnicity, gender, age or family background. At-risk youth grow in environments that are not conducive to their well-being. 


\section{Youths at Risk}

At-risk youths are from families where there is neglect, poverty, violence and other conflicts. Frymier and Gansneder (2001) state that students who were labeled as at-risk had traumatic experiences, such as abuse, poverty and lack of parental guidance during their childhood. The term at-risk also includes youths who are currently functioning well but are at increased risk of developing problems in the future. It is also accurate for these youths to be classified as youth as at-promise (Powell 2015). This is because there are many possibilities of them becoming productive citizens with proper development plans.

According to Slavin and Madden (2004), defining at-risk students could be challenging. They defined at-risk characteristics as retention in grade level, poor attendance, behavioural problems, low socio-economic status or poverty, violence, low achievement, substance abuse and teenage pregnancy. Children were considered at risk if they were likely to fail, either in school or in life. Frymier and Gansneder (2001) observed and evaluated at-risk youths throughout the United States, with 22,018 students from 276 schools as subjects of their research. Twenty-nine percent of the students in the study were considered "seriously at risk"; one out of eight students reported having negative self-esteem and lack of interest in school. According to Etzion and Romi (2015), researchers used risk components that describe behaviour and attitudes deviating from the accepted norm. While they consider reasons such as dropping out from school as objective, they regard the lack of adjustment and other related problems as subjective.

The creation of positive youth development (PYD) perspective is noted as a shift of attention from survival to thriving (Animosa, Johnson and Cheng 2015). According to Catalano et al. (2002), PYD are multifaceted and include resilience, competency, identity development, future orientation and prosocial behaviour. Such standards focus on the development and acquisition of proficiencies rather than prevention of risks.

Youth issues are increasingly recognised as a serious worldwide concern as more studies are being conducted on youth related issues. It is also agreed that most risktaking behaviours peak between the ages of 13 and 16 and they vary according to the support available to adolescence (Gross and Capuzzi 2014). Since little is known about the causes of why individuals get involved in risk behaviour and how they make changes to stop their involvement in such behaviour, it is important to document studies to understand their transformation away from risk behaviour. 


\section{Family, Social Support and Socio-Economic Factors}

The presence of a caring relationship with the family and especially a parent is a good indicator for positive health and education goals (Furstenberg and Hughes 1995; McNeal 1999; Blum and Blum 2009). The American Psychological Association (2019) advocates strongly that parenting practices throughout the world share three major goals such as ensuring children's health and safety, preparing children for life as productive adults and transmitting cultural values. In a study conducted by the Australian Institute of Family Studies by Vassallo, Smart and Robertson (2009), most parents agreed that it was their role to pass on their values and/or life philosophy. Parents are their children's strongest role model and greatest influence. They play crucial roles in shaping their children as quality parenting is important for healthy development. Until the child attends school, parents are the prime educators and a major influence on their children's learning through school and beyond (Ceka and Murati 2016).

According to Ceka and Murati (2016), mothers have prominent roles which are related to the child's defense and overall development. Each child who grows up and is educated in the presence of a mother is expected to attain an appropriate level of physical, psychological and social development. This should be encouraged by the parents themselves by praising, vaunting and rewarding the children on the way they perform and excel. Practicing this education and bringing up methods may be considered as one of the best known examples towards a positive overall approach to the educative and formational function with the children, who later on become successful citizens (Ceka and Murati 2016). Thus, lack of strong positive relationships with parents increases association with deviant peers, which raises adolescents' risk for a variety of problems, including precocious transitions such as early pregnancy, premature independence from parents and dropout from school (Institute of Medicine [US] and National Research Council [US] Committee on the Science of Adolescence 2011).

A parent is the child's first teacher and should remain the best throughout his or her life because the parent plays an important role in shaping his or her behaviour. According to the National Society for the Prevention of Cruelty to Children (2019), one in ten children have experienced neglect. UNICEF has recognised that poor family environment, especially where children are exposed to physical, mental and sexual abuse, as well as neglect, leave children vulnerable to major physical and emotional problems later in life (Fry 2016). The child is most likely to have low self-esteem (The National Academies of Sciences, Engineering and Medicine 2016). 
The lack of strong positive relationships with parents increases involvement with deviant peers, which increases adolescents' risk for a variety of problems, early independence from parents, and being dropouts from school (Institute of Medicine [US] and National Research Council [US] Committee on the Science of Adolescence 2011). Those who were exposed to abuse and violence are likely to become violent people as they grow up believing that violence is the only way to solve issues (The National Academies of Sciences, Engineering and Medicine 2016).

There is also fear of children moving from being attached to parents to being more attached to their peers (Laible, Carlo and Raffaelli 2000). This is especially true since peer pressure has become a huge part in our teenagers' lives as it can affect their output and even impact their general perception of life (Uzezi and Daya 2017). But it can have negative or positive effects where peers can influence decisions about involvement in promotive or prosocial behaviour. Studies have shown that they spend more time observing friends' behaviour and get emotionally attached to them.

Besides parents, mentors also play an important role in aiding the lives of atrisk youth. Rhodes (1997) encouraged mentors to promote the well-being of individuals and schools play an important role in delaying, reducing and reversing involvement in violence. Studies have shown that children with high connectedness to schools are less likely to get involved in deviant behaviours such as fighting, bullying and vandalising (McNeely and Falci 2004; Schaps 2005). The mentor plays an important role by diagnosing a mentee's background and evaluating progress, counselling and guiding, clarifying goals and setting tasks for changes. The mentor acts as a role model and advocate, reviewing academic and social progress, protecting mentee confidentiality, raising mentee self-esteem, listening, encouraging, planning and structuring mentoring sessions, tutoring and providing frank feedback (Rhodes 1997). Rhodes (1997, 68) emphasised that mentors should (1) believe that they can make a difference and instill hope for the future; (2) restore a human-centered base for establishing a connection with a student; (3) work in collaboration with others such as parents, tutors, teachers and counsellors to open doors for students; and (4) enable students to grow emotionally, socially and academically. Influential people like the mentors are strength-based people and when an individual reminds himself of the strength based people in his life, it can increase the chances of taking similar attributes in these youths (Powell 2015). 


\section{THE STUDY}

Using a PYD perspective, this study employs a qualitative method to understand how Indian youths in Malaysia described their lives, the family, social support like school and community that influenced them in their lives and how they made changes to be out of risks. Specifically, this study aimed to share real-life stories of selected Indian youths who have been classified as at-risk. The various problems shared by them can be identified as potential issues that need to be addressed when helping such individuals, especially how they move out of the risk behaviour. These at-risk youths are a concern for the individual himself, the family and the community.

\section{METHODOLOGY}

The study took place in several semi urban places in Kuala Lumpur and Selangor in Malaysia. Initially the researchers began with a pool of 15 youths who were dropouts. These youths were sampled as dropouts and identified as at-risk as they are currently housed in a transformation centre for at-risk youths. They were selected by using purposive sampling taking into consideration their background, and variables related to socio-economic status, dropout from school and single parent environment. Some of them were recommended by social workers and non-governmental organisations (NGOs), and these enabled the researchers to use the snowballing technique. These youths are from 13 to 24 years of age in the development period from childhood through adolescence. Prior to the interview, consent was obtained from the youths. Informants were interviewed at a time and place convenient to them. Participants were advised to skip any question which they did not want to answer.

The final data was obtained from only eight youths (seven others were not comfortable to become informants) via in-depth interviews which were carried out individually. These informants had low literacy rate. Hence, data was collected orally in English and in their mother tongue, Tamil.

Allowing this group of youths to share their stories and experiences and listening carefully and probing them at the relevant issues enabled the researchers to transcribe the data from the recordings. This technique of data collection is unique in nature as the narrative therapy encourages clients to retell their personal stories of past adversity in ways that recall their strengths rather than their weaknesses as victims. They were able to describe their journey from 
"a new, non-problem saturated perspective" (White and Epston 1990, 39). Since the article carries lived experiences of youths, their identities were kept confidential by using pseudonyms. The data was analysed manually line by line and was also verified by an expert in Tamil language to confirm what the youths shared. This was done in a trustworthy manner and reported according to individual informants' account of their path in life.

\section{FINDINGS}

This section reports the narratives shared by the informants individually.

\section{Informant 1}

Informant 1 lives in a low-cost flat. His mother died when he was 10 years old and his father remarried. He has a brother (21 years) and a sister (25 years). His sister is staying with their aunt while the brother was taken care by Informant 1. This informant went to a Tamil primary school and continued to the secondary school. While in Form 1, he needed money to support himself and his brother, so he started to work in a car wash centre. According to him, "At that time, I got a part time job and I got a wage and started looking at the money as big money and I started missing school and going to work to earn more."

Initially, his family was upset that he left school because he did not have any problems in school and was liked by the teachers. However, according to him,

I cannot go back to that life again because I have my family responsibilities. My brother left school in Form 1. I forced him to study but he would run away from school. He worked in a battery company. He was only 13 years old then, so he used to go fishing and hunting and was also pampered by our grandmother.

Now Informant 1 works as a full time car mechanic. He has learned a lot and says that there is more to learn. He reported,

I earn a decent salary and I am happy but I do get tensed up when I cannot repair but after trying hard I can and I am happy. Initially I started with RM300, now I am receiving RM1,600 monthly. Now this salary is for me alone and family but if I have a family or get married, the salary will not be enough. 
He continued,

If I have been given a chance to study, I will worry about my family responsibilities and at the same time I will ask myself can I study, do I have the ability? I have to compete with others who are better than me. I need to learn more and I know having a certificate is important.

He believes that the certificate will help him to be more confident in his work. At the same time, this informant worries that language can become an obstacle to study although he can now support himself financially.

Informant 1 recalled that in the past he had joined some bad hats in his neighbourhood to steal things from neighbours. He said he was involved in many such incidents but was never caught by the police. He said, "I know today people look up to me. They say very nice words about me. These positive words encourage me to work harder and change." When asked about his mentor, Informant 1 said that he considered Mr. Mani (not his real name) as his mentor because:

My mentor is Mr. Mani who saw me at a bicycle shop and offered me work in his motor workshop. I was only 15 then. He genuinely showed interest in me and praised me for my success and the most important thing is he believed in me. In the future, I must have a workshop of my own.

Informant 1 ends by saying he must become someone more respectable and would like to own a motor workshop one day.

\section{Informant 2}

She comes from a family of five. Her father and brother were lorry drivers. Her father passed away at the age of 43 . According to her,

One brother studied marine engineering. Sister has a degree and another sister is in Sarawak. My youngest sister is in Form 6. From the age of 15, I was doing bridal make-up. After Form 5, I started working in a beauty parlor. I was studying IT and have completed two semesters so far. Although my family wants me to study, I am happy working here as the salary is good and my boss teaches me all types of work. I speak in Tamil language at work and friends. I try to read English papers and I have the apps in my phone and I use English to speak to my foreign customers and to the English speaking ones. 
When asked about the reason why she did not continue her study, Informant 2 said, "I don't like to depend on my guardian. That's why I am holding back to study. That's what makes me stressful." This informant is aware that her future is important and commented, "How does the society look at me? In the future I want to work in an IT company. I will do my best for my family and support them financially. For the country, I will help especially school children in future."

\section{Informant 3}

The father of Informant 3 has passed away. She has two sisters and her uncle was her guardian. She stopped schooling because her results were not good. So, she started working as a sales girl. She said she needed to save money for part time studies but it was not possible because her salary was used for family expenditure. According to her, "Physiotherapy was my interest. One sister studied at Infrastructure University Kuala Lumpur, IUKL (a private university) for a degree and the other is doing business administration."

At the age of 20, she started working as a sales girl in a jewellery shop. Her boss helped and taught her a lot. She has worked for seven years in the shop. Her boss treats her like a daughter. She earns a decent salary but would like to look for another job.

\section{Informant 4}

Informant 4 is 16 years old and the eldest son in the family. He is from Dengkil (a semi-urban town in Selangor). His parents operate a food stall. His brother is in Form 3 and his sister is in Standard 5. His grandparents live with them. According to him,

I was very happy to go to a secondary school but only after Form 3, I did not like to be at school. After Pentaksiran Tingkatan 3 (PT3), only two months in school then I left. I saw an electrical course advertised in my school. So, I went to Pusat Kecemerlangan Sepang and completed one year.

He had completed Level 2 and is waiting to complete Level 3. He is proud of himself as he attended classes without any foundation in electrical course. He preferred to study in the centre rather than in school. Since his friends in Form 4 were doing well, he would not encourage them to join him. When asked about his siblings, he said, "as for my brother and sister, I would ask them to complete school and study till university." 
This informant claims to study hard and would sit for his Sijil Pelajaran Malaysia (SPM) later. He goes to a tuition centre to study SPM subjects. He wants to be a chargeman (electrical). Hence, he understands the importance of obtaining a diploma. $\mathrm{He}$ is aware that he has no job prospects without a diploma.

He intends to help his family. He added that he would encourage his friends who do not like to go to school to enroll in an electrical diploma course or learn how to repair mobile phones.

\section{Informant 5}

$\mathrm{He}$ is the fourth child in the family of five siblings. His mother works as a cleaner and his father is a bus driver. He studied in a Tamil primary school and progressed to a national secondary school. In Form 5, he was asked to leave school because he was not interested in studying. He started working part time in a motor shop when he was in Form 1. He did not concentrate in school because he felt work was better. Although he made attempts to go back to school, he was aware that it would not be the same again. According to him, "Teachers used to like me because I was good at sports." He also added that, "My work as a motor mechanic gives me a lot of happiness."

He plans to enroll in an electrical course to obtain a certificate. He used to do the wrong things when he was young. The community looked at him as a misfit because he would pick a fight with anyone. He now regrets his past actions and wants to be a good citizen. He also promised to take care of his mother.

\section{Informant 6}

She comes from a broken family. Her father works in Singapore and does not help her mother and the family. Her mother remarried and now both her mother and stepfather work in Singapore. This informant quarreled with her biological father and moved out to stay with her grandmother in a low-cost flat in Petaling Jaya.

She had a normal school life and studied up to secondary school but her father stopped her schooling. She made several attempts to resume schooling but her father went to the extent of making a police report to stop her from going to school. Hence, the school authorities had to drop her. She has a brother who did an electrical course. 
She is grateful to a voluntary worker who referred her to a NGO. She felt it was a golden opportunity as it changed her life completely. She intends to settle down in life and pursue a Diploma in Legal Secretaryship. Since the organisation gave her a second life, she wants to continue helping it.

She receives RM300 allowance for travelling. Her parents used to ask for the money but they no longer do so. She said that, "My family does not like me because I make decisions now." According to her, "My friends have got married; some work at car wash and my friends have many boyfriends. I don't mix with them. Some are even drug addicts."

On days she went through problems, a voluntary worker at the organisation would give her many activities to keep her mind occupied and she was thankful to her. "My old habits at school cannot be forgiven as I burnt my teacher's car. This teacher was so strict and always picked on me." Currently, Informant 6 works as a teaching assistant with a salary of RM1,800 at the same organisation that helped her.

\section{Informant 7}

Her father died when she was six years old. After her father's death, her mother fell into drug addiction and prostitution. She has two brothers; one is in Kajang and the other brother was given away to a family. She went to school only until Standard 5 (Year 5). She helped her uncle to steal baby products from a supermarket and at a mini market in her neighbourhood. From the age of 11 to 14, she continued stealing for her uncle. According to her,

I was caught by a security guard. I ran away and started staying with a boyfriend who was 22 years old then. I lived for one and a half years with his family. I was helping his mother who was doing some food business. I broke up with him because he had another girlfriend.

At age of 14, Informant 7 tried to go back to school. The school wanted a letter from her parents and the primary school. She had no one to turn to. Her exboyfriend's friend (a girl) took her to an organisation in 2015. Informant 7 is very thankful to the girl. Now, she feels like staying in the organisation all her life, taking care of other girls like her. After being in that place, she says that she no longer loses her temper quickly and is now a better person. She said, "In the past, I met drug addicts and now I have the chance to meet good and caring people." 
She wants to complete Levels 4 and 5 for a Diploma in Secretaryship. She also plans to get a driving license by next year. She said, "I have no allowance now because the previous year I misused all my money on friends. I am still changing for the better but it is hard."

\section{Informant 8}

She studied until Form 5 but failed in a compulsory subject in SPM. She beat up her friends because they used to speak bad about her parents and it became a police case. So, she started avoiding friends. She worked in a cafe and did a sales job when she needed to. Her aunt referred her to an organisation but her parents were not happy. Her father does wiring work and her mother is employed in a factory. She said, "My parents are in Ipoh and I can only call them once a week."

She helps other students in the organisation with problems and guides them to do their assignments. She likes the courses as it helps her to think. She has graduated and she continues to help for the organisation for a small allowance. She said, "The organisation and the team there helped me control my anger. Sometimes I felt like running away because I am not allowed to use the handphone." Informant 8 understands that she has to transform to be a better person. She also hopes to re-sit the subject that she failed in SPM, so that she can obtain her school certificate.

\section{DISCUSSION}

Based on the above findings, it is clear that all the eight informants face some common problems in their lives. This section will discuss three main common problems faced by these youths (informants) in their lives that are socioeconomic situation or poverty, family instability and dropout from school.

\section{Socio-Economic Situation}

Based on the findings, six out of eight informants faced socio-economic problems. The informants came from low-income families. They faced financial difficulties and this factor induced them to go for part-time jobs. For example, Informant 1 lived in a low-cost flat and faced financial problem when he was in Form 1. Initially, he started to work part time in a car wash centre, but after he started receiving salary, he began to skip school. In the case of Informant 2, 
she stopped schooling because she did not want to depend on her family. Although there was some support as she lived with a guardian, this informant did not want to be dependent on her guardian and become a financial burden. Informant 5 also came from a low-income family where his mother works as a cleaner and his father as a bus driver. Based on the experience of those informants, socio-economic hardship is one of the factors which forced them to stop schooling. The economic instability of their families played a key role in pushing them out of school and to start working. They worked not only for self-support but also to help their family members.

\section{Family Environment}

The family unit is an important and integral aspect of life and community. The family is the backbone for the success of most people, especially youths. Based on the interviews with the informants, we found that four informants faced family instability. Informant 1's family was not stable and cohesive after his mother passed way. He had to take care of his brother while his sister was staying with his aunt. In order to support himself and his brother, he had to work. Informant 2 was with a guardian and shouldered the financial burden of the family. She put her study on hold because of the financial implication although she is aware of her future. Informant 3 also faced the same predicament after her father's death. She and her two sisters were taken care of by her uncle as a guardian. Although she planned to save for her part-time study, she was not successful as the money was spent for family expenditure.

On the other hand, Informants 6 and 7 faced worse situations compared to other informants. Informant 6's father did not help her mother and the family. The mother remarried another man. The mother, the biological father and the stepfather were never at home because they work in distant places. Hence, she was forced to stay with her grandmother. Informant 7's father passed away when she was six years old. She faced difficulties when her mother became a drug addict and got involved in prostitution. Due to the hardship, one of her brothers was given away to a family for adoption. At a very young age, she was influenced by her uncle to steal. Finally, she ran away and got into a relationship at a young age.

The family instability contributed to the problems faced by the informants. Although there were some forms of support within the family circle, it did not make matters better for these informants as the support was considered weak. Strong family support is considered important especially for these young 
informants. These children had to stop schooling, started earning at a very young age and a few of them were drawn into social ills. Such situations are evidence of the risk behaviour faced by these "kids." Their lives would have been different if they had received the appropriate family support and guidance.

\section{Dropout from School}

Students who do not complete basic primary and secondary education are considered school dropouts. Based on our findings, six out of eight informants were dropouts from school either at the primary or lower secondary levels. These informants were either pushed out of the system or left voluntarily. The socioeconomic difficulties and family instability are the main contributing factors for these children to drop out of school.

School dropout is a crucial issue that needs to be taken seriously. Once a student stopped schooling at an early age, he or she faces the prospect of losing opportunities for upward mobility. These students have less chances of going for higher education or enrolling in skill-based institutions. In fact, they also have difficulties getting employed with an appropriate living salary since they have not completed primary or lower secondary school. Furthermore, they are at risk of being involved in many social ills when they started working at a young age and without the much needed parental support and guidance. Without adequate support of the family, the school would have been the only institution left to play the important role of imparting basic education and providing emotional support for these children.

\section{CONCLUSION}

Youths form the largest segment of the population and they are a valuable asset to the nation. They are the future of any society and play an important role in the development of a nation. However, some of these youths are exposed to social ills due to poverty and family instability and are at risk of becoming a burden to society. The study indicates that youths who are engaged in risk behaviours are capable of making some changes to their lives and to embark on positive paths if they are provided with proper guidance and support. Assets are positive factors within the individual such as competence, coping skills and self-efficacy while resources are made up of crucial external factors like parental support, adult mentoring and communication that promote youth development. 
Given the setting and context of the study and the high risk environment the informants grew up in, the findings showed some positive transitions that they have undergone. The findings also tell us that given the right training and coaching, they can become useful young adults. This is also in line with the study by Animosa, Johnson and Cheng $(2015,68)$ who concluded that "youths traditionally classified as bad kids can and do change when given the right support." The findings clearly reflect on the PYD through resilience. Although there is a huge concern with risk exposure among them, they focused on strengths rather than deficits during their journey. The findings show their development in spite of risk exposure. Hence, the promotive factors can help youths avoid the negative effects of risks.

These talented youths are at times forgotten because of their behaviour in the past. However, these youths deserve the right to obtain basic education and acquire positive values just like the rest of their peers and be empowered back into the society. Hence, the right intervention is needed and they should be given the required support and mentoring that can help mould them with the right attitude and values. Effective intervention must be planned in order to stop this group from further developing negative behaviour. This can only become a reality through synergy with relevant parties, especially NGOs that can play the role of providing resources in their lives.

As most qualitative research, the sample size does not allow for generalisation. The findings suggest pertinent issues to be raised in future research conducted to better understand the family and circumstances which at-risk youths grow up in. Finally, constructing a typology of youths at-risk based on adolescents' personality attributes on their behavioural attributes will enable more effective intervention and the creation of setting that are more appropriate to each individual within the group.

\section{ACKNOWLEDGEMENTS}

This study was funded by Geran Universiti Penyelidikan (GUP-2017-097). 


\section{REFERENCES}

Animosa, L.H., S.L. Johnson and T.L. Cheng. 2015. "I used to be wild": Adolescent perspectives on the influence of family, peers, school and neighbourhood on positive behavioral transition. Youth \& Society 50(1): 49-74. https://oi.org/ 10.1177/0044118X15586146

American Psychological Association. 2019. Parenting. https:/www.apa.org/topics/ parenting (accessed 27 June 2018).

Berita Harian. 2019. Dewan Negara lulus pindaan akta turunkan had umur belia kepada 30 tahun. 24 July. https://www.bharian.com.my/berita/nasional/2019/07/588802/ dewan-negara-lulus-pindaan-akta-turunkan-had-umur-belia-kepada-30 (accessed 5 December 2019).

Blum, L.M. and R.W. Blum. 2009. Resilience in adolescence. In Adolescent health: Understanding and preventing risk behaviors, eds. R.J. DiClemente, J.S. Santelli and R.A. Crosby, 51-61. Hoboken, NJ: John Wiley.

Catalano, R.F., M.L. Berglund, J.A. Ryan, H.S. Lonczak and J.D. Hawkins. 2002. Positive youth development in the United States: Research findings on evaluations of positive youth development programs. Prevention \& Treatment 5(1): 15a. https://doi.org/10.1037/1522-3736.5.1.515a

Ceka, A. and R. Murati. 2016. The role of parents in education of children. Journal of Education and Practice 7(5): 61-64.

Etzion, D. and S. Romi. 2015. Typology of youth at risk. Children and Youth Services Review 59: 184-195. https://doi.org/10.1016/j.childyouth.2015.10.017

Fry, D. 2016. Preventing violence against children and how this contributes to building stronger economies. Thematic research paper for the 3rd high-level meeting on Cooperation for Child Rights in the Asia-Pacific Region, 7-9 November. Kuala Lumpur: Government of Malaysia and the United Nations Children's Fund (UNICEF).

Frymier, J. and B. Gansneder. 2001. The Phi Delta Kappa study of student at-risk. Phi Delta Kappan 71: 142.

Furstenberg, F.F. and M.E. Hughes. 1995. Social capital and successful development among at-risk youth. Journal of Marriage and the Family 57: 580-592. https://doi.org/10.2307/353914

GrapeSEED. 2018. How poverty affects education \& our children. https://grapeseedus. com/how-poverty-affects-education-children/ (accessed 10 August 2018).

Gross, D.R. and D. Capuzzi. 2014. Defining youths at risk. In Youths at risk: A prevention resource for counselors, teachers and parents, eds. D. Capuzzi and D.R. Gross, 3-22. Alexandria: American Counseling Association.

Institute of Medicine (US) and National Research Council (US) Committee on the Science of Adolescence. 2011. The science of adolescent risk-taking: Workshop report. Washington, DC: The National Academies Press.

Institute of Medicine and National Research Council. 2011. The science of adolescent risk-taking: Workshop report. Washington, DC: The National Academies Press. https://doi.org/10.17226/12961. 
Laible, D.J., G. Carlo and M. Raffaelli. 2000. The differential relations of parent and peer attachment to adolescent adjustment. Journal of Youth and Adolescence 29: 45-59. https://doi.org/10.1023/A:1005169004882

McNeal, R.B. 1999. Parental involvement as social capital: Differential effectiveness on science achievement, truancy, and dropping out. Social Forces 78(1): 117-144. https://doi.org/10.2307/3005792 https://doi.org/10.1093/sf/78.1.117

McNeely, C.A. and C. Falci. 2004. School connectedness and the transition into and out of health-risk behavior among adolescents: A comparison of social belonging and teacher support. Journal of School Health 74(7): 284-292. https://doi.org/ 10.1111/j.1746-1561.2004.tb08285.x

Powell, K.M. 2015. A strength-based approach for intervention with at-risk youth. Illinois: Research Press Publishers.

Public Health Scotland. 2019. Adverse childhood experiences. http://www.healthscotland. scot/population-groups/children/adverse-childhood-experiences-aces/overviewof-aces (accessed 28 March 2018).

Rhodes, D. 1997. Operation rescue: Reaching at-risk students through teacher initiatives. Paper presented at the annual meeting of the American Research Association, Washington, DC. April.

Schaps, E. 2005. The role of supportive school environments in promoting academic success. In Getting results: Developing safe and healthy kids (Update 5), ed. California Department of Education. https:/www.collaborativeclassroom.org/ wp-content/uploads/2017/12/getresults5_ch3Schaps.pdf (accessed 10 August 2018).

Slavin, R. and N. Madden. 2004. Students at-risk of school failure: The problem of its dimensions. Boston: Allyn and Bacon.

The National Academies of Sciences, Engineering and Medicine. 2016. Federal policies and investments supporting parents and children in the United States. In Parenting matters: Supporting parents of children ages 0-8, eds. V.L. Gadsden, M. Ford and H. Breiner, 101-124. Washington, DC: The National Academies Press.

United Nations Educational, Scientific and Cultural Organization (UNESCO). 2016. Youth. https://unevoc.unesco.org/home/TVETipedia+Glossary/filt=all/id=9

United Nations. 2001. Implementation of the world programme of action for youth to the year 2000 and beyond. https://www.youthpolicy.org/basics/2001_WPAY_ Implementation_Report.pdf

Uzezi, J.U. and G.D. Daya. 2017. Relationship between peer group influence and students' academic achievement in chemistry at secondary school level. American Journal of Education Research 5(4): 350-356.

White, M. and D. Epston. 1990. Narrative means to therapeutic ends. New York: W.W. Norton.

Zimmerman, M.A. 2013. Resiliency theory: A strengths-based approach to research and practice for adolescent health. Health Education and Behavior 40(4): 381-383. https://doi.org/10.1177/1090198113493782 